This item was submitted to Loughborough's Research Repository by the author.

Items in Figshare are protected by copyright, with all rights reserved, unless otherwise indicated.

\title{
The subscription list for Jean Adam’s Miscellany Poems (1734)
}

PLEASE CITE THE PUBLISHED VERSION

PUBLISHER

C) Oxford University Press

LICENCE

CC BY-NC-ND 4.0

REPOSITORY RECORD

Overton, W.J.. 2019. “The Subscription List for Jean Adam's Miscellany Poems (1734)”. figshare. https://hdl.handle.net/2134/286. 
This item was submitted to Loughborough's Institutional Repository by the author and is made available under the following Creative Commons Licence conditions.

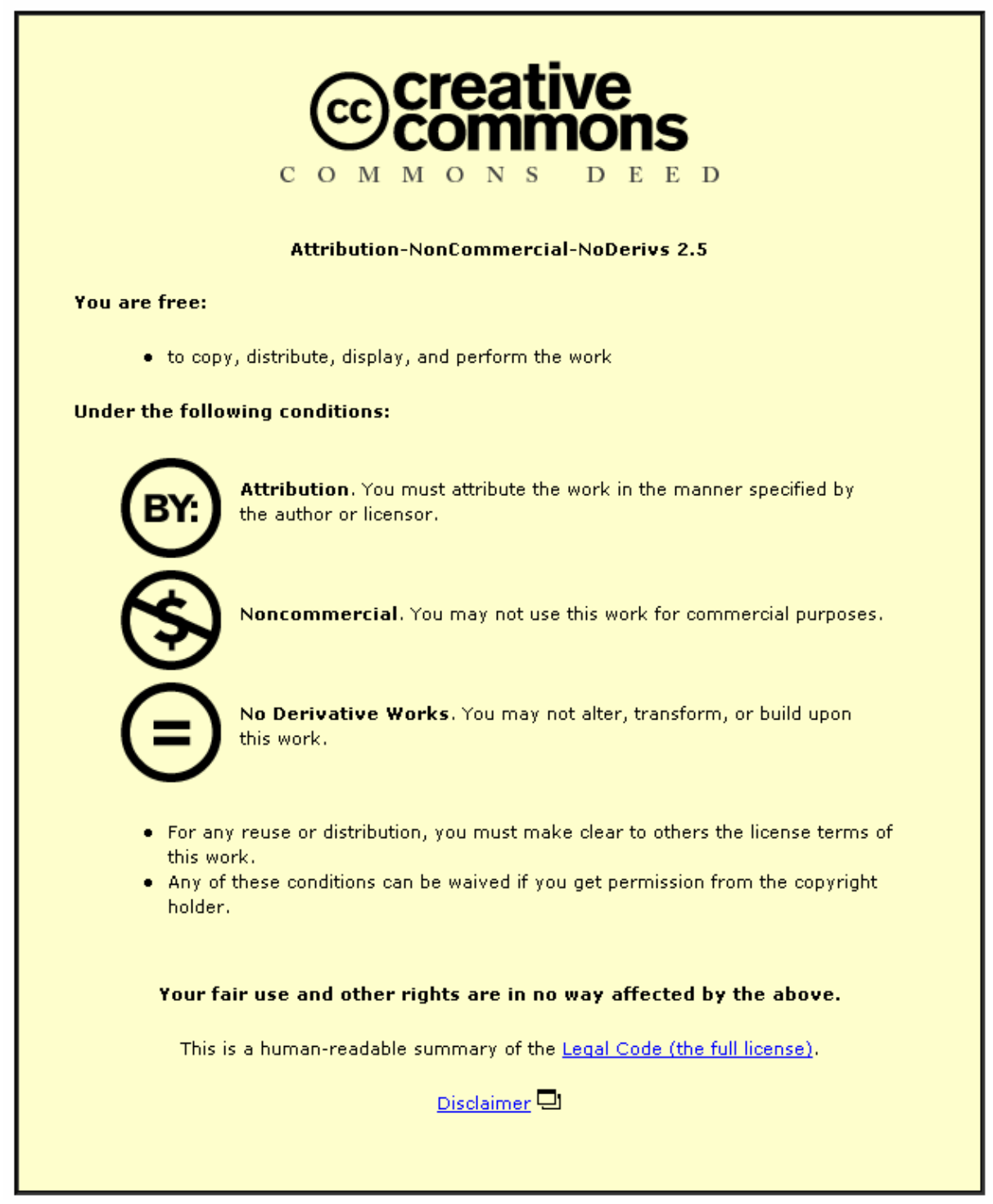

For the full text of this licence, please go to: http://creativecommons.org/licenses/by-nc-nd/2.5/ 